\title{
Benthic Macroinvertebrates Diversity and Physical-Chemical Parameters as Indicators of the Water Qualities of Ntawogba Creek Port Harcourt Nigeria
}

\author{
Umunnakwe Johnbosco Emeka ${ }^{1,}$, , Uyi Hanson Sylvanus², Umunnakwe Bernadine Akuoma ${ }^{3}$, \\ Deekae Suanu Nanee ${ }^{4}$ \\ ${ }^{1}$ Department of Environmental Management, Federal University of Technology, Owerri, Nigeria \\ ${ }^{2}$ Institute of Pollution Studies (Ecology/Hydrobiology Dept.), Rivers State University, Port Harcourt, Nigeria \\ ${ }^{3}$ Department of Science Education, Ignatius Ajuru University of Education, Port Harcourt, Nigeria \\ ${ }^{4}$ Department of Fisheries and Aquatic Environment, Rivers State University, Port Harcourt, Nigeria
}

Email address:

jnboscokwe@yahoo.com (U. J. Emeka)

${ }^{*}$ Corresponding author

\section{To cite this article:}

Umunnakwe Johnbosco Emeka, Uyi Hanson Sylvanus, Umunnakwe Bernadine Akuoma, Deekae Suanu Nanee. Benthic Macroinvertebrates Diversity and Physical-Chemical Parameters as Indicators of the Water Qualities of Ntawogba Creek Port Harcourt Nigeria. American Journal of Chemical and Biochemical Engineering. Vol. 4, No. 1, 2020, pp. 8-17. doi: 10.11648/j.ajcbe.20200401.12

Received: January 24, 2020; Accepted: March 9, 2020; Published: March 31, 2020

\begin{abstract}
The study evaluated the water qualities of Ntawogba creek by utilizing the benthic macroinvertebrates diversity as well as physical-chemical parameters data, to give us an indication of the biochemical condition and health of the river. The research was carried out for twelve (12) months, firstly by establishing three (3) main sampling stations and their co-ordinates along the stretch of the creek based on ecological niche of the stream and human activities on the study area. The physicalchemical parameters measured and analysed include, Temperature, pH, Electrical Conductivity, Salinity, Turbidity, Total Dissolved Solids, Dissolved Oxygen and Biochemical Oxygen Demand, according to APHA 1998 standard methods. Sediment particle size was determined by hydrometer method. Replicate samples of benthic macroinvertebrates were collected from each station randomly with Eckmann's grab. The results of the physical-chemical data were subjected to 2-way analysis of variance and differences among means where separated by Turkey-Honest significant difference at $95 \%$ probability. Percentage occurrence and relative numerical abundance of macroinvertebrates were calculated using excel descriptive statistical tool. Diversity of the benthos was determined using Shannon Wiener index hequitability of species. The results showed that $\mathrm{pH}$ values ranged from mild acidic to alkalinity (6.42 to 7.63). The values of turbidity, TDS, BOD and DO exceeded limits of World Health Organization in most of the sampling stations. The sediment particles of the stream were significantly dominated by sand fractions with the highest mean recorded in station three $(74.08 \pm 0.71)$. The total number of benthic macroinvertebrates individuals in the sampled stations was 28,730 and total number of species was 40 . The diversity, taxa richness and evenness recorded at station one were $0.823,1.934$ and 0.683 , while station two had $0.605,1.163$ and 0.605 and station three had 0.301 , 3.085 and 0.206 . The results show that the human activities grossly polluted the stream, and constant monitoring is required to safeguard the waterbody and aquatic ecosystem in the study area.
\end{abstract}

Keywords: Phyisical-Chemical, Diversity, Macroinvertebrates, Water, Ntawogba, Parameters

\section{Introduction}

Benthic macroinvertebrates (also known as "benthos") are small animals living among stones, logs, sediments and aquatic plants on the bottom of streams, rivers and lakes [1].
They are large enough to see with the naked eye (macro) and have no backbone (invertebrate), and examples include molluscs, annelids, crustaceans, chordates, arthropods, 
coelentrates etc. [2]. The organisms are also found dwelling in or on filamentous algae for some part of their life circle [3]. Different types of macroinvertebrates tolerate different stream conditions and levels of pollution. Their presence or absence are commonly used as indicators of the biological condition of water bodies to indicate clean or polluted water; long enough to reflect the chronic effects of pollutants, and yet short enough to respond to relatively acute changes in water quality.

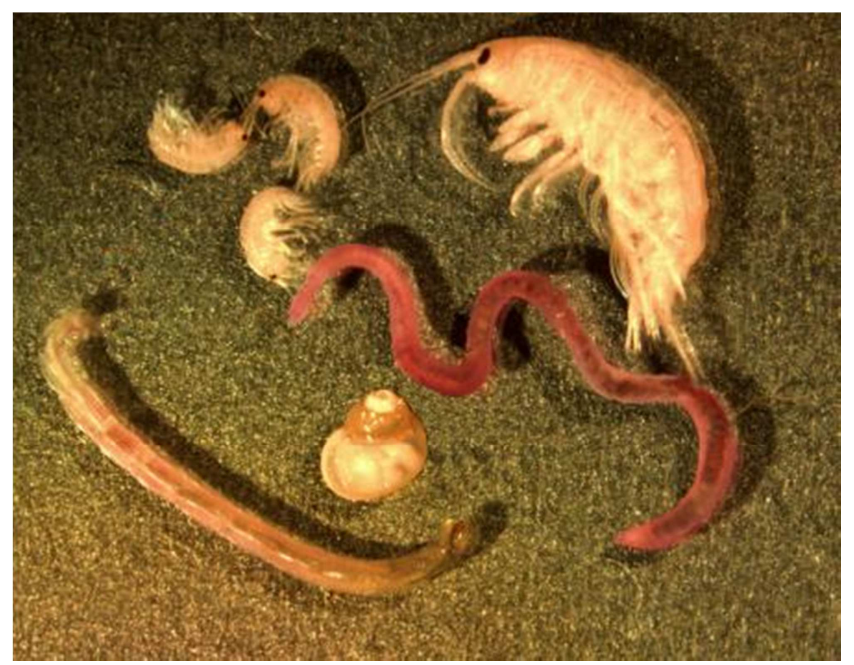

Figure 1. Variety of benthic macroinvertebrates viewed under a stereo microscope. Source: G. Carter via NOAA/GLERL (2016).

Unlike fish, these populations tend to be relatively immobile, and as a result are continuously exposed to the constituents of the surface water they inhabit. Thus, because of the limited mobility of macroinvertebrates and their relative inability to move away from adverse conditions, the location of chronic sources of pollution often can be pinpointed by comparing communities of these organisms [4]. Generally, waterbodies in healthy biological condition support a wide variety and high number of macroinvertebrate taxa, including many that are intolerant of pollution. Samples yielding only pollution-tolerant species or very little diversity or abundance may indicate a less healthy water body. When the biology of a waterbody is healthy, the chemical and physical components of the waterbody are also typically in good condition [5].

Benthos is utilized as food items for a wide range of organisms in water including fish some of which are consumed by man [6]. Most of the organisms themselves feed on the detritus that settle or grow on the bottom substrate and also shuttle movement between the sediment and the water column thereby accelerating the breakdown of decaying larger organic matters into simpler inorganic forms such as phosphates, nitrates etc.[7].

The composition, distribution and abundance of benthic macrofauna can be influenced by physical, biological and chemical environmental factors [8] and [9]. In Port Harcourt the pace of urban development and industrial activities is fast increasing, so also do the amounts of wastes generation increasing around the city and its environ [10].

Domestic and industrial waste contents of toxic substances are continuously being discharged daily into the aquatic systems with or without proper treatment, thus causing serious water pollution problems [11]. They provide more accurate understanding of the changing aquatic conditions than chemical and microbiological data which at least give short time fluctuations [12]. The inability of the organisms to move effectively away from their habitat pre-supposes that those benthos are deemed to be exposed to ecological danger. These features and other peculiar characteristics of the benthic fauna such as longer life span, abundance and size, render them useful as potential environmental indicators [13].

\section{Method}

\subsection{The Study Area}

Ntawogba stream is a tributary of the Bonny River located at the upper reaches off the Bonny river estuary in the Niger delta of Nigeria. It lies between latitude $4^{\circ} 48^{\prime}, 4^{\circ} 4^{\prime} 7$ North and longitude $6^{\circ} 58^{\prime}, 6^{\circ} 01^{\prime}$ East of Port Harcourt city. It is a meandering stream that traverses almost the entire width of Port Harcourt and harbors several residential communities and industrial companies along its bank with different activities like waste dumps, vehicle repair/car wash, sand mining, boat building/repairs, fishing, recreation and drainage construction, etc.

\subsubsection{Sampling Stations}

Three main sampling stations were established along the stretch of the stream based on ecological niche of the system. Station 1, is located between Abacha and Okija street, the stream at this section is none tidal fresh water and flows in one direction, draining through residential and commercial areas (Figure 1).

The main activities here are bathing, car wash, mechanic work, welding and mining of sand and waste dump. This section of stream is walled with concrete embankment (Plate 2 and 3 ).

The position of station 2 is between Kaduna Street and Aba/Port Harcourt express way. The area is tidal fresh water zone. The tidal action is minimal, but still drains in one direction through a dense residential and commercial area. The stream is also walled with concrete embankment with floating algal mass (Plates 4 and 5). Human activities are car wash, welding, mechanic work and waste dumping.

Station 3 is located between Amadi flats and Eastern bypass. It is a tidal brackish water ecological zone with mangrove characteristics (Plates 6 and 7). The main human, industrial and commercial activities taking place here are fishing, bathing, car wash, sand mining/dredging, boat building, jetty operations, transportation by the use of canoe and motorized vessels. 


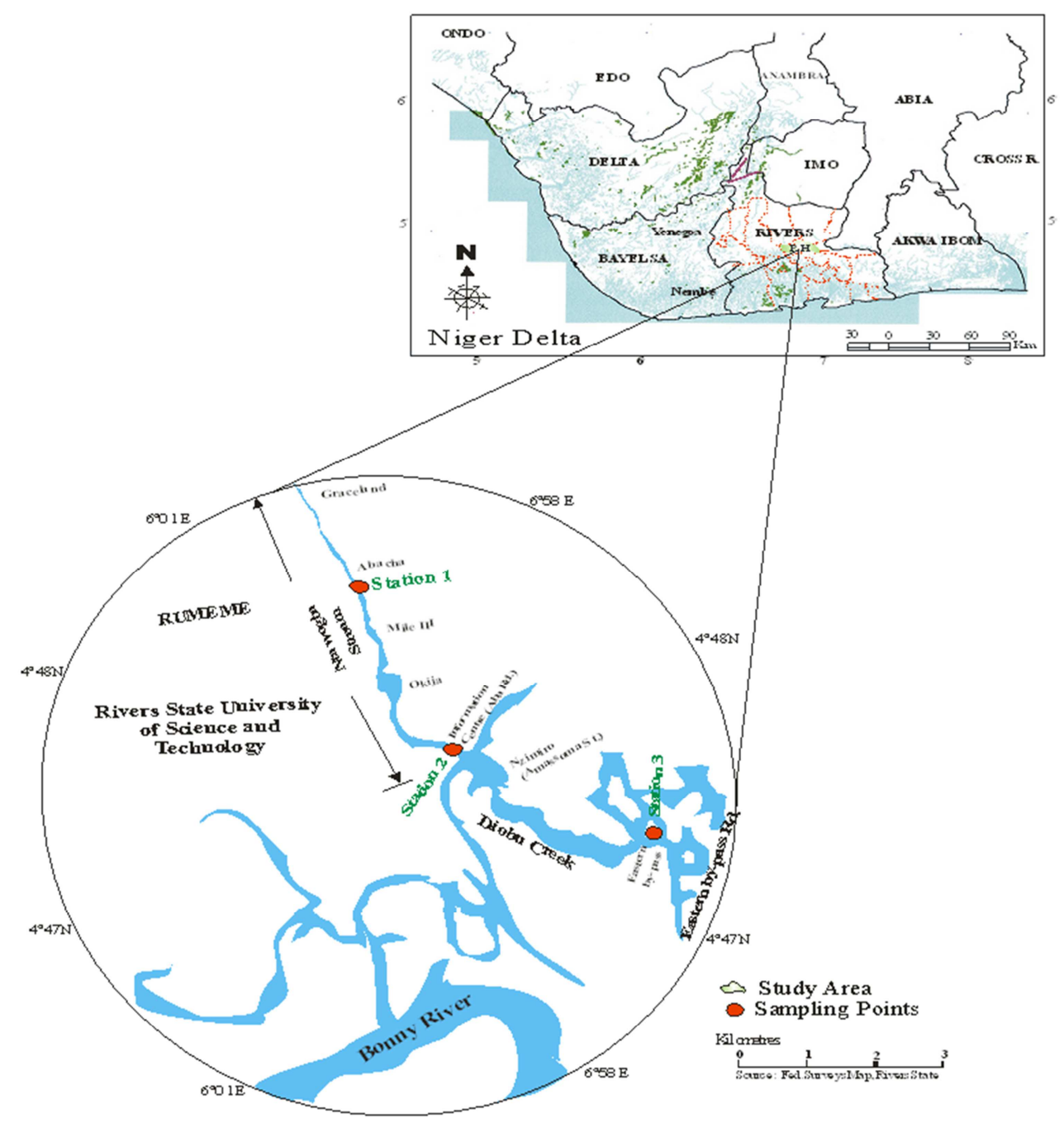

Figure 2. Map of Niger Delta showing Ntawogba Stream in Port Harcourt Nigeria (The Study Area).

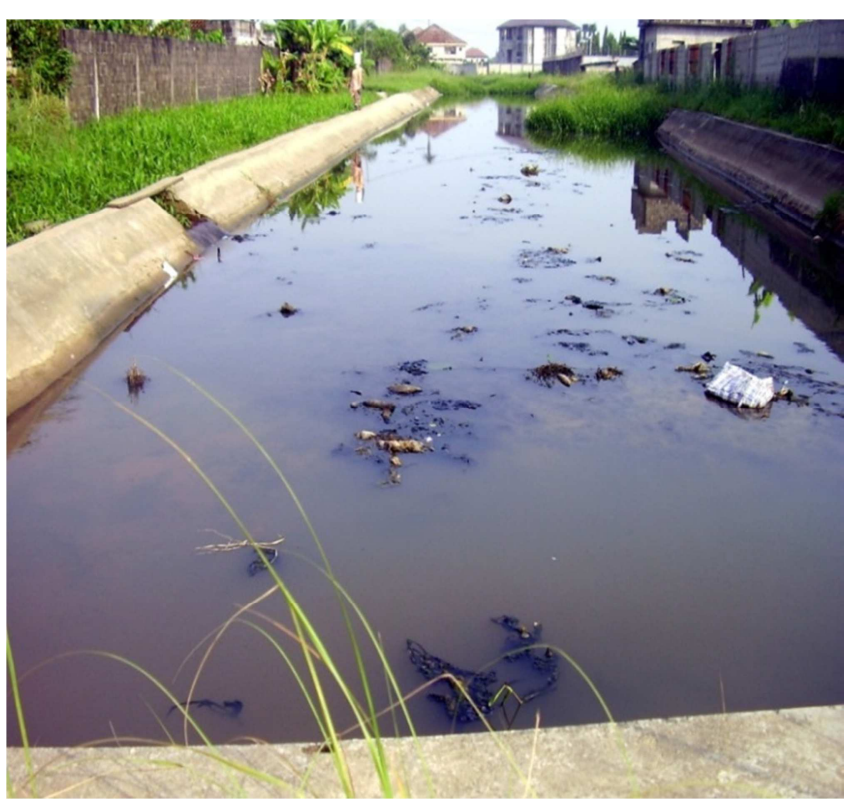

Figure 3. Station 1-showing the Upstream part of the study Area (Abacha axis).

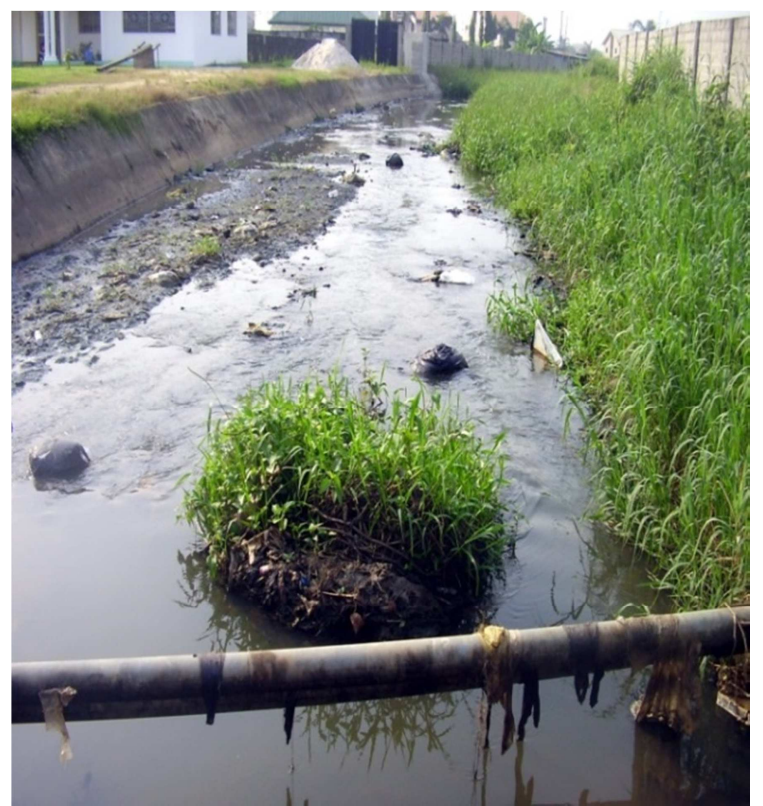

Figure 4. Station 1-showing the Downstream part of the Study Area (Abacha axis). 


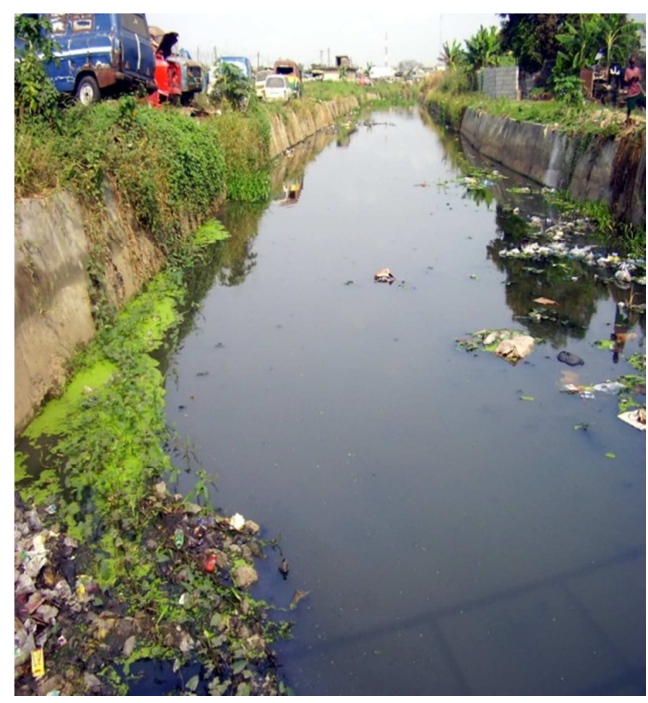

Figure 5. Station 2-showing the Upstream part of the Study Area (Okija axis).

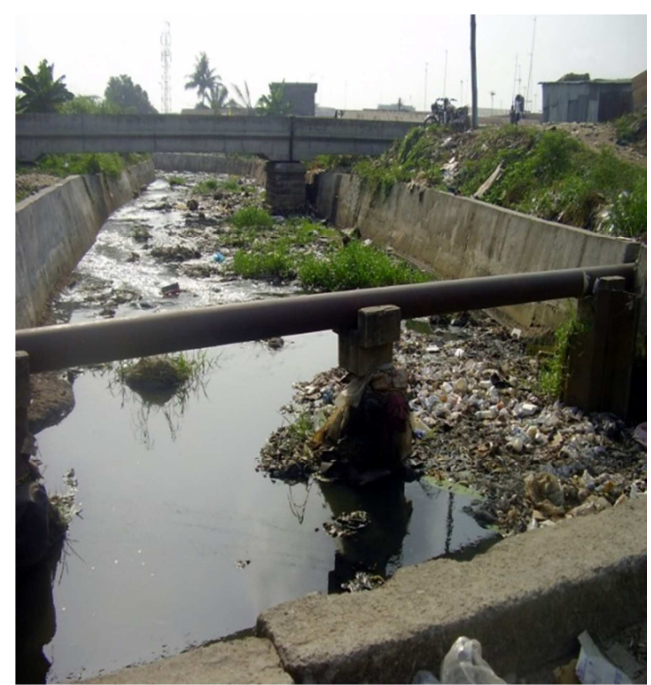

Figure 6. Station 2-showing the Downstream part of the Study Area (Okija axis).

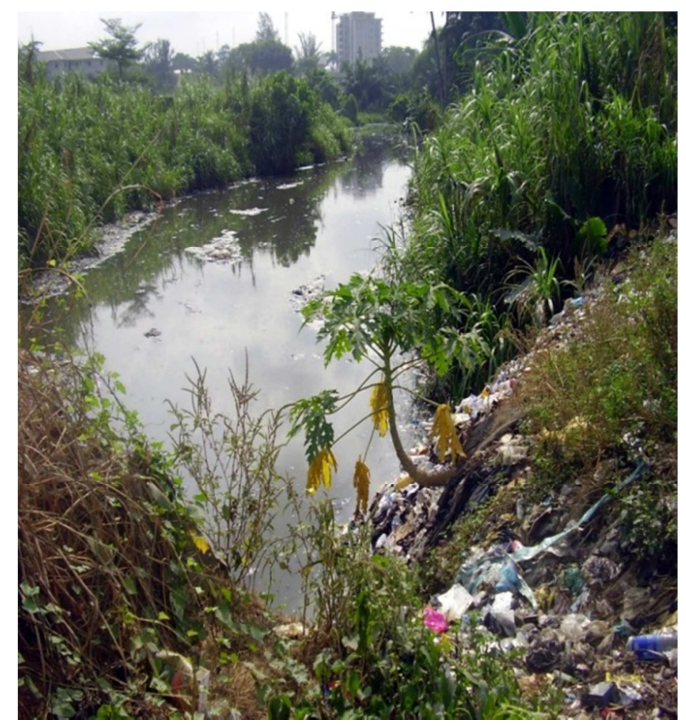

Figure 7. Station 3-showing Upstream part of the Study Area (EasternBypass).

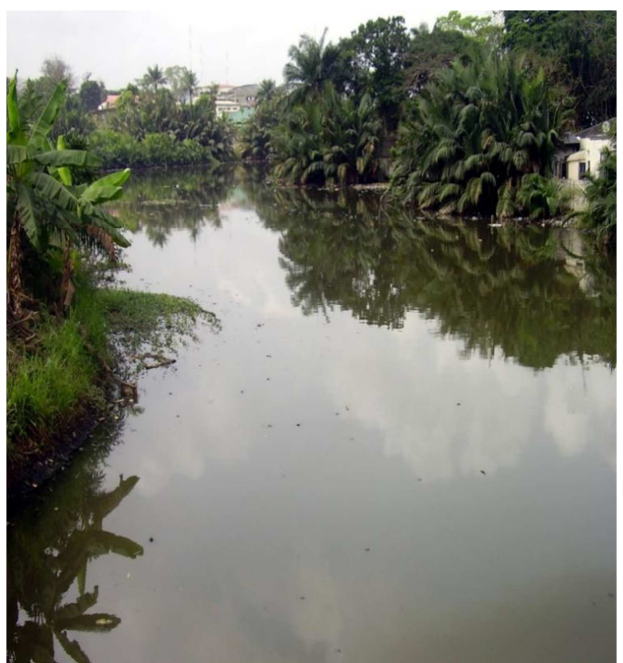

Figure 8. Station 3-showing the Downstream part of the Study Area.

\subsubsection{Sampling and Analysis}

Rainfall data were retrieved from the records of the Federal Ministry of Aviation, department of meteorological services, federal secretariat, Port Harcourt. The physical and chemical parameters studied were Temperature, Hydrogen ion concentration $(\mathrm{pH})$, Electrical Conductivity, Salinity, Turbidity, Total Dissolved Solids, (TDS), Dissolved Oxygen (DO), and Biochemical Oxygen Demand (BOD). The methods used were as described by [14]. The water temperature was measured in situ using mercury in glass thermometer $\left(0-50^{\circ} \mathrm{C}\right)$, by immersing the sensitive part of the thermometer directly into the water and, the temperature value read from three readings in the sampling stations and the mean values calculated and recorded. The water $\mathrm{pH}$, electrical conductivity, Salinity, Turbidity and Total dissolved solids were measured in-situ using a multiple-probe Horiba water checker (model U-10 $0^{\mu}$ ) by dipping the probe into the water sample after calibration and standardized with reagent and distilled water. The arrow key was positioned on the measured parameters, and the value taken and recorded after the calculation of the mean value. Surface water samples for the measurement of Dissolved Oxygen (DO) were collected and determined according to the modified Azide or Winkler's method [14].

Water sample for Bio-chemical Oxygen Demand (BOD) was collected in the same way as DO, but the samples were left to incubate for 5 days in the dark at temperature of about $20^{\circ} \mathrm{C}$. To avoid using all the oxygen by the aerobic microorganisms during the 5-day period, the BOD samples were diluted before incubation to determine the dilution factor and the $\mathrm{BOD}_{5}$ calculated [14].

\subsection{Sediment Study}

Sediment particle size was determined by the hydrometer method [14]. The freshly collected sample from the field was air dried under the ceiling fan for a period of five days. The well dried sediment was crushed with laboratory mortar and pestle then sieved through a $2 \mathrm{~mm}$ mesh size sieve; and transported to the laboratory for further treatment and 
analysis.

\subsection{Benthic Macro-invertebrate}

Replicates samples of benthos were collected from each sampling station randomly, with Eckmann's grab measuring $16 \mathrm{~cm}^{2} \times 16 \mathrm{~cm}^{2}$ to collect the sediment at the depth of about $15 \mathrm{~cm}$. The grab was retrieved by pulling the line after which the grab was opened and sediment sample taken to the laboratory for subsequent treatment and analysis [15].

Benthic macro-invertebrates in the vials were emptied into petri dish and mounted on the microscope for examination and counting the numbers of species of each taxa. The organisms were identified taxonomically to the possible lowest levels using the best keys, such as [16-18].

\subsection{Data Analysis}

Physico-chemical data from the stations were subjected to 2 way analysis of variance. Differences among means were separated by Tukey Honest significant differences at $95 \%$ probability. Percentage occurrence and relative numerical abundance of macro benthos were calculated using excel descriptive statistical tools. Densities of the abundant species were analyzed for each of the sampled stations. Diversity of the benthic invertebrates was determined using Shannon Wiener Index, Equitability (E) of species [19, 20] Margalef Diversity index.

\section{Result}

The rainfall data obtained from Federal Ministry of Aviation, Port Harcourt, showed that the total annual rainfall for the year was $2,852.8 \mathrm{~mm}$. Temperature ranged between $26.04^{\circ} \mathrm{C}$ and $33.05^{\circ} \mathrm{C}$ and increased spatially in the order $3>2>1$ across stations. The $\mathrm{pH}$ values of Ntawogba surface water were between 6.54 and 7.83 across stations and values decreased downstream.

Table 1. Variation in Range, Mean and Standard Deviation in Physico-chemical Parameters of different Stations of Ntawogba Stream.

\begin{tabular}{|c|c|c|c|}
\hline & & Stations & \\
\hline Parameters & Stn 1 & Stn 2 & Stn 3 \\
\hline \multirow{2}{*}{ Temperature ${ }^{\circ} \mathrm{C}$} & $26.04-32.52$ & $28.04-33.05$ & $26.12-31.03$ \\
\hline & $29.78 \pm 0.67^{\mathrm{b}}$ & $30.34 \pm 0.50^{\mathrm{a}}$ & $29.88 \pm 0.47^{b}$ \\
\hline \multirow{2}{*}{$\mathrm{Ph}$} & $6.59-7.83$ & $6.74-7.72$ & $6.42-7.63$ \\
\hline & $7.08 \pm 0.15^{\mathrm{a}}$ & $7.07 \pm 0.10^{\mathrm{a}}$ & $6.86 \pm 0.12^{\mathrm{b}}$ \\
\hline \multirow{2}{*}{ Conductivity $(\mu \mathrm{S} / \mathrm{cm})$} & $187.0-8,037.0$ & $320.0-20180.0$ & $1,504.0-33,905.0$ \\
\hline & $1,313.28 \pm 673.15 \mathrm{c}$ & $3,227.09 \pm 1,703.62^{b}$ & $16,944.29 \pm 2,286.65^{\mathrm{a}}$ \\
\hline \multirow{2}{*}{ Turbidity (NTU) } & $4.0-204.0$ & $12.0-782.0$ & $1.0-25.0$ \\
\hline & $47.79 \pm 25.29^{b}$ & $107.92 \pm 68.32^{\mathrm{a}}$ & $9.67 \pm 2.21^{\mathrm{c}}$ \\
\hline \multirow{2}{*}{ TDS (mg/l) } & $131.0-5626.0$ & $224.0-14126.0$ & $5422.0-24,439.0$ \\
\hline & $970.29 \pm 457.27^{\mathrm{c}}$ & $2,252.92 \pm 1,190.40^{\mathrm{b}}$ & $14,160.92 \pm 1,857.39^{\mathrm{a}}$ \\
\hline \multirow{2}{*}{ Salinity (\%o) } & $0.05-0.5$ & $0.1-5.7$ & $0.5-19.1$ \\
\hline & $0.11 \pm 0.04^{\mathrm{c}}$ & $1.43 \pm 0.55^{\mathrm{b}}$ & $10.50 \pm 0.89^{\mathrm{a}}$ \\
\hline \multirow{2}{*}{ Do (mg/l) } & $1.23-3.65$ & $0-2.61$ & $2.04-7.11$ \\
\hline & $2.60 \pm 0.32^{b}$ & $0.62 \pm 0.20^{c}$ & $3.94 \pm 0.55^{\mathrm{a}}$ \\
\hline \multirow{2}{*}{$\mathrm{BOD}(\mathrm{mg} / \mathrm{l})$} & $5.55-19.04$ & $66.22-28.07$ & $5.34-17.02$ \\
\hline & $13.29 \pm 5.00^{\mathrm{b}}$ & $15.23 \pm 6.32^{\mathrm{a}}$ & $11.51 \pm 4.28^{\mathrm{c}}$ \\
\hline
\end{tabular}

${ }^{\mathrm{a}-\mathrm{c}}$ Means with different superscripts in the same column are significantly different at $\mathrm{p}>0.05$ (Tukey HSD).

The mean conductivity values recorded across the stations varied from $725.33 \pm 392.28 \mu \mathrm{S} / \mathrm{cm}$ to $20,734.00 \pm 7,495$ $\mu \mathrm{S} / \mathrm{cm}$ (Table 1). Turbidity ranged between 1.00 and 782.00 NTU with mean varying significantly from $8.33 \pm 5.46$ to $332.33 \pm 231.63$ NTU across the stations. There was spatial variation with a trend that showed higher turbidity values in stations 2 (782.0 NTU) than station 3 (1.0 NTU). The mean total dissolved solids values ranged between $1,939.67 \pm 1741.26 \mathrm{mg} / \mathrm{l}$ to $14,514.00 \pm 5,247.08 \mathrm{mg} / 1$ across the stations with significant difference at $(\mathrm{p}<0.05)$.

The range of values for mean salinity recorded varied from $1.47 \pm 1.39 \mathrm{ppt}$ to $8.08 \pm 5.41 \mathrm{ppt}$ across the stations with significant difference at $\mathrm{p} \leq 0.05$.

Mean values of surface water Dissolved Oxygen concentrations were between $1.56 \pm 1.01 \mathrm{mg} / \mathrm{l}$ and $3.73 \pm 1.71 \mathrm{mg} / 1$ across the stations. Spatial observation showed that a higher dissolved oxygen value was recorded in station $3(7.11 \mathrm{mg} / \mathrm{l})$ than in station $2(0 \mathrm{mg} / \mathrm{l})$, with values significantly different at $\mathrm{p} \geq 0.05$. The mean Biochemical Oxygen Demand ranged between $5.78 \pm 0.62 \mathrm{mg} / \mathrm{l}$ and $22.55 \pm 7.81 \mathrm{mg} / 1$ across the stations spatially, BOD had maximum value at Station $2(28.07 \mathrm{mg} / \mathrm{l})$ and lowest at Station $3(5.34 \mathrm{mg} / \mathrm{l})$. The relationship between DO and BOD showed an inverse proportionality.

Generally, sediment particles of the stream were significantly dominated by sand fractions ( $p \geq 0.05$ ). There was a tendency of spatial increases in sand content with highest mean values of sand recorded in station 3 $(7.4 .08 \pm 0.7 \%)$. The highest mean value $(14.09 \pm 2.33 \%$ was in station 3 and lowest $(7.74$ CC. $76 \%)$ in station 2 . The result of the study for the sediment showed that three textural classes were common in the area as follows; station 1 (sandy loam), station 2 (sandy) and station 3 (loamy sand). 
Table 2. Spatial Range, Mean and Standard Deviation in Sediment Particles along Ntawogba Stream.

\begin{tabular}{llll}
\hline & Stations & & \\
\hline Parameters & Stn 1 & Stn 2 & Stn3 \\
\hline Sand (\%) & $67.39-78.85$ & $66.33-75.30$ & $69.17-77.19$ \\
& $73.10 \pm 1.12^{\mathrm{a}}$ & $71.72 \pm 0.85^{\mathrm{a}}$ & $74.08 \pm 0.71^{\mathrm{a}}$ \\
Silt (\%) & $12.68-21.17$ & $14.20-21.24$ & $11.67-15.10$ \\
& $17.50 \pm 0.90^{\mathrm{a}}$ & $10.98 \pm 0.62^{\mathrm{c}}$ & $13.38 \pm 0.48^{\mathrm{b}}$ \\
Clay (\%) & $5.23-12.33$ & $3.66-12.44$ & $10.70-15.73$ \\
Textural Class & $9.29 \pm 0.72^{\mathrm{c}}$ & $8.96 \pm 0.81^{\mathrm{b}}$ & $12.55 \pm 0.75^{\mathrm{a}}$ \\
\hline
\end{tabular}

Means with different superscript letters in the same column are significantly different at $\mathrm{p}>0.05$ (Tukey HSD)

A total of forty (40) species of benthic fauna occurred in Ntawogba stream during the period of study. Three phyla: Annelida, Arthropoda, and Mollusca were recorded in the benthic samples (Table 3); the phylum Annelida dominated the community, represented by the classes Oligochaeta and Polychaeta. The class Oligochaeta had three representative families (Enchytridae, Lumbricidae, and Naididae) with nine species (68.7\%). The Polychaeta had ten (10) families (Arenicolidae, capitellidae, Eunicidae, Glyceridae, Nephthyidae, Nereidae, Sabelidae, Spionidae, Syllidae and Terrebridae (30.1\%).

The crustacean subphylum Malacostraca had 3 representative families (Taitridae, Gammaridae, and Peneidae), Insecta had 2 families (Chironomidae and Culicidae) and three species (0.4\%). Gastropoda was represented by four families (Bulinidae, Pilidae, Planobidae and Physidae) which had a total of 5 species $(0.7 \%)$. Bivalvia was represented by a lone family (Pinnidae) and one taxon.

Table 3. Checklist of Benthic Macro-invertebrate in Ntawogba Stream During the study period.

\begin{tabular}{|c|c|c|c|c|c|}
\hline $\mathbf{S} / \mathbf{N}$ & Phylum & Class & Order & Family & Genus \\
\hline \multirow{29}{*}{1} & ANNELIDA & Oligochaeta & Chaetopoda & Enchytridae & Lumbricilus $s p$ \\
\hline & " & $"$ & $"$ & Lumbricidae & Eiseniella tetrahidra \\
\hline & " & $"$ & $"$ & Naididae & Chaetogaster diastrophus \\
\hline & ” & " & ” & " & Dero obtuse \\
\hline & ” & $"$ & $"$ & ” & Ophidonais serpentina \\
\hline & ” & ” & $"$ & ” & Nais $s p$ \\
\hline & ” & $"$ & $"$ & $"$ & Paranais $s p$ \\
\hline & " & " & ” & " & Stylaria lacustris \\
\hline & 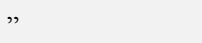 & & ” & $”$ & Uncinais uncinata \\
\hline & & & " & & \\
\hline & " & Polychaeta & $"$ & Arenicolidae & Arenicola neamarina \\
\hline & " & & $"$ & Capitellidae & Capitella capitata \\
\hline & 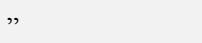 & " & ” & $"$ & Heteromastus filiformis \\
\hline & $"$ & " & ” & $”$ & Notomastus tenuis \\
\hline & " & $"$ & " & $"$ & Notomastus abaraans \\
\hline & $"$ & ” & ” & ” & Notomastus latricieus \\
\hline & ” & $"$ & $"$ & Eunicidae & Diopatra capensis \\
\hline & $"$ & " & " & Glyceridae & Glvcinde armingera \\
\hline & " & $"$ & $"$ & $"$ & Glycera capitata \\
\hline & " & " & ” & " & Glvcera convoluta \\
\hline & $"$ & $"$ & $"$ & Nephthyidae & Nephthys hombergi \\
\hline & $"$ & $"$ & ” & Nereidae & Nerieis diversicolor \\
\hline & $"$ & ” & ” & $"$ & Nereis virens \\
\hline & $"$ & $"$ & " & $"$ & Nerieis pelagica \\
\hline & $"$ & $"$ & $"$ & Sabellidae & Fabricia capensis \\
\hline & $"$ & " & ” & Spionnidae & Polydora capensis \\
\hline & ” & $"$ & " & " & Syllis prolifera \\
\hline & “ & " & “ & “ & Syllis fulceligera \\
\hline & “ & $"$ & “ & Terrebridae & Amphitrite neajohanstoni \\
\hline \multirow{6}{*}{2} & ARTHROPODA & Malacostroca & Amphipoda & Taiitridae & Amphithoe rubricata \\
\hline & & " & Amphipoda & Gammaridae & Gammarus lacusta \\
\hline & “ & $"$ & Decapoda & Peneidae & Peneus notialis \\
\hline & $"$ & Insecta & Diptera & Chironomidae & Chironomus ablabiesmia \\
\hline & $"$ & & $"$ & Culicidae & Choaborus corethra \\
\hline & " & $"$ & " & $"$ & Culex molestus \\
\hline \multirow{5}{*}{3} & MOLLUSCA & Gastropoda & Pulmonata & Bulindae & Bullinus globuscus \\
\hline & $"$ & 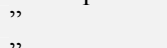 & $"$ & & Bullinus forskali \\
\hline & $"$ & ” & ” & Pilidae & Pila ovata \\
\hline & $"$ & $"$ & $"$ & Planobidae & Planobis albus \\
\hline & $"$ & Bivalvia & Pelecypoda & Solecurtidae & Tagelus andasonii \\
\hline
\end{tabular}

Table 4. Density, Distribution and Relative Abundance of Benthic Macro-invertebrates in the Stations at Ntawogba Stream During the study period.

\begin{tabular}{|c|c|c|c|c|c|c|c|}
\hline \multirow{2}{*}{$S / N$} & \multirow{2}{*}{ Species } & \multicolumn{6}{|c|}{ STATIONS } \\
\hline & & 1 & 2 & 3 & Total & $\%$ of Organism & $\%$ of Class \\
\hline & $\begin{array}{l}\text { ANNELIDA } \\
\text { Oligochaeta }\end{array}$ & & & & & & \\
\hline 1 & Lumbricilus $s p$ & 1,806 & 627 & 5 & 2,438 & 8.49 & \\
\hline
\end{tabular}




\begin{tabular}{|c|c|c|c|c|c|c|c|}
\hline \multirow{2}{*}{$\mathbf{S} / \mathbf{N}$} & \multirow{2}{*}{ Species } & \multicolumn{6}{|c|}{ STATIONS } \\
\hline & & 1 & 2 & 3 & Total & \% of Organism & \% of Class \\
\hline 2 & Eiseniella tetrahidra & 4,316 & 132 & - & 4,448 & 15.48 & \\
\hline 3 & Chaetogaster diastrophus & 670 & 3 & - & 673 & 2.34 & \\
\hline 4 & Dero obtusa & 1,719 & 27 & 5 & 1,751 & 6.09 & \\
\hline 5 & Ophidonais serpentina & 258 & 15 & - & 273 & 0.95 & \\
\hline 6 & Nais $s p$ & 4,540 & 294 & 47 & 4,881 & 16.99 & \\
\hline 7 & Paranais $s p$ & 529 & 18 & - & 547 & 1.90 & \\
\hline 8 & Stylaria lacustris & 181 & 60 & - & 241 & 0.84 & \\
\hline 9 & $\begin{array}{l}\text { Uncinais uncinata } \\
\text { Polychaeta }\end{array}$ & 3,379 & 1,104 & 2 & 4,485 & 15.61 & 68.1 \\
\hline 10 & Arenicola neamarina & - & - & 8 & 8 & 0.03 & \\
\hline 11 & Capitella capitata & - & - & 337 & 337 & 1.17 & \\
\hline 12 & Heteromastus filiformis & - & - & 11 & 11 & 0.04 & \\
\hline 13 & Notomastus tenuis & - & - & 38 & 38 & 0.13 & \\
\hline 14 & Notomastus abarans & - & - & 569 & 569 & 1.98 & \\
\hline 15 & Notomastus latericieus & - & - & 14 & 14 & 0.05 & \\
\hline 16 & Diopatra capensis & - & - & 5 & 5 & 0.02 & \\
\hline 17 & Glycinde armingera & - & - & 10 & 10 & 0.03 & \\
\hline 18 & Glycera capitata & - & - & 2 & 2 & 0.01 & \\
\hline 19 & Glycera convoluta & - & - & 3 & 3 & 0.01 & \\
\hline 20 & Nephthys hombergi & - & - & 21 & 21 & 0.07 & \\
\hline 21 & Nereis diversicolor & - & - & 62 & 62 & 0.22 & \\
\hline 22 & Nereis virens & - & - & 26 & 26 & 0.09 & \\
\hline 23 & Nerieis pelagica & - & - & 3 & 3 & 0.01 & \\
\hline 24 & Fabricia capensis & - & - & 58 & 58 & 0.20 & \\
\hline 25 & Polydora capensis & - & - & 7,463 & 7,463 & 25.98 & \\
\hline 26 & Syllis prolifera & - & - & 5 & 5 & 0.02 & \\
\hline 27 & Syllis fulceligera & - & - & 15 & 15 & 0.05 & \\
\hline 28 & $\begin{array}{l}\text { Amphitrite neajohonstoni } \\
\text { ARTHROPODA } \\
\text { Crustacean }\end{array}$ & - & - & 3 & 3 & 0.01 & 30.1 \\
\hline 29 & $\begin{array}{l}\text { Crustacean } \\
\text { Amphithoe rubricata }\end{array}$ & - & - & & & & \\
\hline 30 & $\begin{array}{l}\text { Ampnithoe rubricata } \\
\text { Gammarus lacusta }\end{array}$ & - & - & $\begin{array}{l}8 \\
8\end{array}$ & $\begin{array}{l}8 \\
8\end{array}$ & 0.03 & \\
\hline 31 & $\begin{array}{l}\text { Peneus notialis } \\
\text { Insecta }\end{array}$ & - & - & $\begin{array}{l}8 \\
5\end{array}$ & $\begin{array}{l}8 \\
5\end{array}$ & $\begin{array}{l}0.03 \\
0.02\end{array}$ & 0.1 \\
\hline 32 & Chironomus ablabiesmia & 58 & 15 & 6 & 79 & 0.27 & \\
\hline 33 & Choaborus corethra & - & - & 5 & 5 & 0.02 & \\
\hline 34 & $\begin{array}{l}\text { Culex molestus } \\
\text { MOLLUSCA } \\
\text { Gastropoda }\end{array}$ & 17 & - & - & 17 & 0.06 & 0.4 \\
\hline 35 & Bullinus globuscus & 5 & - & - & 5 & 0.02 & \\
\hline 36 & Bullinus forskali & 5 & - & - & 5 & 0.02 & \\
\hline 37 & Pila ovata & 35 & - & - & 35 & 0.12 & \\
\hline 38 & Planobis albus & 5 & - & - & 5 & 0.02 & \\
\hline 39 & $\begin{array}{l}\text { Physa fantinalis } \\
\text { Bivalvia }\end{array}$ & 165 & - & - & 165 & 0.57 & 0.7 \\
\hline 40 & Tagelus andasonii & - & - & 3 & - & 0.01 & 0.0 \\
\hline & Total No. of Individuals & 17,688 & 2,295 & 8,747 & 28,730 & - & - \\
\hline & Percentage & 61.57 & 7.98 & 30.45 & 100 & 100 & 100 \\
\hline & $\begin{array}{l}\text { Total No. of species } \\
\text { Diversity } \\
\text { Taxa richness } \\
\text { Evenness }\end{array}$ & $\begin{array}{l}16 \\
0.823 \\
1.534 \\
0.683\end{array}$ & $\begin{array}{l}10 \\
0.605 \\
1.163 \\
0.605\end{array}$ & $\begin{array}{l}29 \\
0.301 \\
3.085 \\
0.206\end{array}$ & 40 & - & - \\
\hline
\end{tabular}

The pattern of distribution and relative abundance is presented in Table 4. Oligochaeta species such as Lumbricilus, Nais sp. and Uncinata sp. were present in all the stations. The class Polychaeta, Amphipoda, Crustacea, and Bivalvia species were only recorded in station 3 (brackish water zone), while the Gastropoda species were restricted to station 1, the upstream freshwater zone. Meanwhile the class Insecta had 3 species of which Chironomus ablabiesmia was recorded in all stations, Chaoborus corethra occurred only in station 3, and culex molestus was restricted to upstream freshwater station 1. Generally, station 1 had maximum density $\left(17,688\right.$ individuals $\left./ \mathrm{m}^{2}\right)$, while the lowest density was recorded in station $2\left(2,295\right.$ individuals $\left./ \mathrm{m}^{2}\right)$.

As shown in Table 4, species richness peaked at Station 3, followed by Station 1. In contrast, general diversity (Shannon-Wiener Index) was highest at Station $1>2>3$. The individuals were also more evenly distributed at Station 1, followed by Station 2 . 


\section{Discussion}

The results of the physical-chemical condition of Ntawogba stream, Port Harcourt, Nigeria revealed that surface water temperature ranged from $26.04^{\circ} \mathrm{C}$ to $33.05^{\circ} \mathrm{C}$. The observed temperature value in the area agrees with the results from previous works in the Niger Delta [21-24]. $\mathrm{pH}$ values of the surface water of Ntawogba Stream showed a transition from mild acidic to mild alkalinity along the various stations investigated. Electrical conductivity values observed in Ntawogba stream indicate transition from fresh water to Marine. The general trend of conductivity values below $1000 \mu \mathrm{S} / \mathrm{cm}$ indicates fresh water and higher above $1000 \mu \mathrm{S} / \mathrm{cm}$ as brackish and above $40,000 \mathrm{~m} \mu \mathrm{S} / \mathrm{cm}$ as marine. Turbidity range was between 1.00NTU and 782.00NTU across stations. Total Dissolved Solids (TDS) and Turbidity results showed spatial variations along the stretch of the stream. Total dissolved solid concentration increased as one proceeded downstream [25]. They attributed such result to the contribution of industrial effluent and the increased effects of soil erosion. Salinity values of range between $0.05 \mathrm{ppt}$ and $19.05 \mathrm{ppt}$ indicate that the upstream is a fresh water ecological zone while the downstream is a brackish water ecological system. Dissolved Oxygen (DO) values showed that higher values were recorded in downstream than upstream. Effluent discharge caused a significant decrease in the dissolved oxygen concentration of river water, due to high BOD load [26]. The observed lower values of dissolved oxygen across the stations may be due to discharges of effluent rich in organic matter into the aquatic system which could depress oxygen level to zero, and the impact of oxygen consuming waste discharged into the river system between the points [27]. At the point of the entry of the effluent discharge, there is always a sharp decline in the concentration of oxygen in the water, known as the oxygen sag [28].

Biochemical Oxygen Demand (BOD) results showed values that were generally high with mean values ranged between 4.72 and $68.21 \mathrm{mg} / \mathrm{l}$ across stations. High BOD recorded across the stations could be as a result of increase in biodegradable organic substances in the study sites and activities of micro-organisms added to the stream through effluent and those present that utilize available oxygen as they breakdown the organic matter [29, 30]. The particle sizes of sediment in Ntawogba stream revealed three textural groups namely: sandy loam, sandy and loamy sand. The sediment particles were generally dominated by sand fractions. Similar works in the Niger delta such as [31, 32] reported that silt and clay contributed more to the total weight of sediments in the central axis of Bonny estuary than fine sand fractions, and also the sediment particles decreased downstream.

Forty taxa belonging to 23 families and 7 classes of benthic invertebrate were recorded during the study. The study from Eagle Island mangrove swamp of Niger Delta [13] reported forty three species of macrofauna, [33], recorded twenty (23) species of macroinvertebrates in New Calabar River. The study of the zoobenthos of Andoni flats showed twenty eight families, six classes from five Phyla [34]. Thirty taxa belonging to twenty families and five classes of macroinfauna in Woji Creek on the upper reaches of Bonny estuary Niger Delta [13]. Fourteen species representing eleven families of macroinvertebrates were identified in Imo River [35]. Also, another work recorded a dominance of crustaceans, insects, molluscs and annelids in the lower Niger Delta river [36]. From the result of this study it may be suggested that differences in species composition, distribution and abundance recorded may be attributed to both differences in ecological, physiological, adaptations and environmental characteristics. On a station-by-station basis, the distribution pattern of the benthic macroinvertebrates was different. The four species of oligochaetes (Lumbricilus sp, Dero obtuse, Nais [sp and Uncinais uncinata were recorded from at least two of the three sampled locations. By contrast, all 19 polychaete species encountered were restricted to station 3; amphipodes and crustaceans exhibited same sitespecific occurrence.

Gastropods, however, were only recorded in station 1 . The Insecta, Chironomus occurred in (station 1, 2 and 3), while Chaoborus Coualitative measurements urethra was recorded only at station 3 . The observed trend may be linked to differences in salinity tolerance; while the widely distributed species were euryhaline, those with limited distribution were oligohaline [37]. These relationships suggest that waterbodies can be fully characterized by three major components: hydrology, physico-chemistry and biology. They can also be described through a range of quantitative and qualitative measurements such as physical-chemical and biological tests, species inventories and biotic indices [38].

\section{Conclusion}

The findings from the research showed that the composition, distribution and abundance of benthic macro invertebrates were influenced by physical, biological and chemical environmental factors such as total dissolved solids, biochemical oxygen demand, dissolved oxygen, nature of bottom deposits and contaminants entering the aquatic system. Biochemical Oxygen Demand (BOD) results showed values that were generally high with a sharp decline in the concentration of oxygen in the water, known as the oxygen sag. This might be as a result of presence of and the breakdown of discharged organic matter by micro-organisms, which utilize oxygen to the detriment of the Ntawogba stream biota. Total dissolved solid concentration increased as one proceeded downstream due to the contribution of industrial effluent and the increased effects of soil erosion. The research findings showed paucity in the species richness and general diversity at the study stations which were attributed to pollution along the stretch of the creek. Species diversity of benthos in the study area compared favourably with those of similar environment in the Niger Delta. It is recommended that: periodic studies of benthic macro invertebrates of Ntawogba stream are carried to keep track with the environmental changes overtime. Moreso, stringent 
environmental protection measures should be enforced to regulate waste discharges into the integrity of the systems.

\section{References}

[1] N. Jordan "Benthic macroinvertebrates surveys" The Enviroscience, enviroscience/employee,. 2019,. vol. 1, pp. 1015.

[2] R. D Barnes, and Hughes "An introduction to marine ecology”, United Kingdom: Blackwell Scientific Publications, 1988, pp. 20-35.

[3] 'E. A. Ajao, and S. O. Fagade "The benthic macroinfauna of Lagos Lagoon" The Zoologist, 2002, vol. 2, pp, 1-5.

[4] M. Sujay, P. Fatmawati, H, Agoes-Sucipto "BenthicMacroinvertebrates Diversity as Bioindicator of water quality of some Rivers in East Kalimantan Indonesia", International Journal of Ecology, 2018, http://doi.org/10.1155/2018/5129421.

[5] G. Cartavia, "Guide to Aquatic Invertebrates, West" Virginia department of environmental protection, 2016, vol. 3, pp, 2-4, deep. wv.gov/WWE/watershed/bio fish.

[6] E. O. Idowu, and A. A. A. Ugwumba, "Physical, chemical and benthic faunal characteristics of a southern Nigeria reservoir", The Zoologist, 2005, vol. 3, pp. 15-25.

[7] A. A. Adebisi, "The physico-chemical hydrology of a tropical seasonal river upper Ogun River", Hydrologia, 1980, vol. 79, pp. 159-165.

[8] W. O. Odiete, "Environmental physiology of animals and pollution", Lagos: Diversified Resources Publication, 1999, pp. 32-45.

[9] R. B. Ikomi, F. O Arimoro, and O. K Odihirin,. "Composition, distribution and abundance of macroinvertebrates of the upper reaches of River Ethiope, Delta State, Nigeria." The Zoologist, 2005, vol 3, pp, 68-81.

[10] J. E Umunnakwe,. I. K. E Ekweozor, and B. A Umunnakwe, "Impact of lifestyle scenarios on household waste in Port Harcourt", Management of Environmental Quality: An International Journal, 2019 vol, 30 (4), pp, 864-889.

[11] O. Obire, D. C Tamuno, and S. A Wemedo,. "Physicochemical quality of Elechi Creek in Port Harcourt, Nigeria", Journal of Applied Sciences of Environmental Management, 2003. vol 7, pp 41-49.

[12] O Ravera, "Ecological monitoring for water body management". Proceedings of monitoring Tailor-made III. International Workshop on Information for Sustainable Water Management, 2000, pp. 45-60.

[13] N Zabbey, and A. I. Hart, "Influence of some physicochemical parameters on the composition and distribution of benthic fauna in Woji Creek, Niger Delta, Nigeria", Global Journal of Pure \& Applied Science, 2006, vol 12, pp. 1-5.

[14] APHA American Public Health Association, Standard methods for the examination of water and waste water. 20th edition, Washington DC, USA, 1998.

[15] A. C Chindah. and A. I Hart, "Occurrence and distribution of epifauna and infauna community in shallow mangrove wetland in tropical West African region". African Journal of Environmental Studies, 2001 vol, 1, pp. 76-83.

[16] J. H Day, "The ecology of the Morrumbene estuary", "Mocambigue Transition Reseach Socities of South Africa", 1974, pp 41, 43-97.

[17] J Edmunds. "Sea shells and other molluscs found on West African shores and estuaries". 1978, Ghana, University Press, pp. 32-43.

[18] R. W. Pennak, "Freshwater invertebrates of the United States", 1978, New York: John Wiley and Sons, pp. 43-56.

[19] P. J. Sheeshan, "Effects on community and ecosystem structure and dynamics", "In: Effects of Pollutants at the Ecosystem Level", Singapore:John Wiley and Sons, 1984, pp 30-38.

[20] R. Margalef,. "Diversity and stability: A practical proposal and a model of interdependence", Brookhaven Symposium of Biology, 1967. vol 22, pp. 25-27.

[21] N. Zabbey,. "An ecological survey of benthic macroinvertebrates of Woji Creek off the Bonny river system", 2002 Rivers State. (Unpublished Masters Thesis), University of Port Harcourt, Rivers State, Nigeria.

[22] E. J. Ansa, "Studies of the benthic macrofauna of the Andoni flats in the Niger Delta area of Nigeria". (Unpublished Doctorial Thesis) 2005, University of Port Harcourt, Nigeria.

[23] A. I. Hart, and N. Zabbey, "Physico-chemistry and benthic fauna of Woji Creek in the Lower Niger Delta, Nigeria" Journal of Environment and Ecology, 2005, vol 23, pp 361368 .

[24] A. C Chindah, S. A Braide,. and J. N Onwuteaka,"Vertical distribution of Periphyton on woody substrate in the brackish wetland embayment of Bonny River, Niger Delta". Biologia, 2005, vol 5, pp. 97-108.

[25] I. O Odokuma,. and G. C Okpokwasili. Seasonal influences of the New Calabar River, Nigeria", Environmental Monitoring and Assessment, 1996, vol, 5, pp. 1-14.

[26] C. N Coimbra,. M. A. S Graca,. \& R. M Cortes, "The effects of a basic effluent on macroinvertebrate community structure in a temporary Mediterranean river". Journal of Environmental Pollution, 1996, vol 94, pp. 301-307.

[27] O. E. Atobatele, O. A. Morenikeji, and O. A. Ogunba, "Spatial variation in physical and chemical parameters and benthic invertebrate fauna of river Ogunpa, Ibadan", The Zoologist, 2005, vol, 3, pp. 58-67.

[28] E. T. Tyokumbur, T. G., Okorie, A. O. Ugwumba, "Limnological assessment of the effect of effluents on Macroinvertebrates fauna in Awoba stream and reservoir, Ibadan, Nigeria", The Zoologist, 2002. pp. 1, 59-69.

[29] R. N, McNeely, V. P, Neimanis, and L Dwyer. "Environment" Canada: Water quality sources-A guide to water quality parameters, 1979, pp 45-67.

[30] C. F. Mason, "Biology of fresh water pollution", New York: Edition. Welley and Sons Incorporated, $2^{\text {nd }} 1992$,. pp. 351.

[31] E Ombu, "Impacts of Okrika oil terminal on Bonny river estuary" (Unpublished Masters Thesis), Rivers State University of Science and Technology, Port Harcour, 1987, pp 43-50. 
[32] J. D Allan, "Stream Ecology-Structure and function of running waters" New York: Chapman and Hall, 1995, pp. 3245 .

[33] O. C, Umeozor, "Benthic fauna of New Calabar River, Nigeria", Tropical Fresh water. Biology, 1995, pp, 4, 41-51.

[34] S. M Nelson,. and D. M Lieberman," The influence of flow and other environmental factors on benthic macroinvertebrates in the Sacramento river, USA",. Hydrobiologia, 2002. vol, 489, pp 117-129.

[35] N. Zabbey, F. D Sikoki,. and J Edoghotu,. Plankton assemblages and environmental gradient in the middle reaches of the Imo River, Niger Delta, Nigeria. African Journal of Aquatic Science, 2008 vol, 33, pp 241-248.
[36] C. S Nwadiaro, "The longitudinal distribution of macroinvertebrates and fish in the lower Niger Delta River (River Sombreiro) in Nigeria", Hydrobiologia Bulletin, 1987, vol, 18, 133-140.

[37] P. R Campbell, A. M; Janette, M. K Webber, and, F. Dale.” Planktonic communities as indicators of water quality in mangrove Lagoons; a Jamaican case study". Transitional waters Bulletin. 2008, vol 3, pp,: 39-63.

[38] T. A, Adesalu, O. A, Kunrunmi \& M. O Lawal, " Water quality assessments: A case study of Plankton and Macrobenthic invertebrates of Porto-Novo and parts of Gulf of Guinea". Journal of Aquatic Sciences, 2016, Vol 31 (1), pp $39-42$. 